\title{
IMMUNOLOGICAL SCREENING FOR SPECIFIC PROTEIN CONTENT IN BARLEY SEEDS
}

by

\author{
ULLA RASMUSSEN \\ Department of Biotechnology, Carlsberg Research Laboratory, \\ Gamle Carlsberg Vej 10, DK-2500 Copenhagen Valby \\ and \\ Department of Physiology, Carlsberg Laboratory, \\ Gamle Carlsberg Vej 10, DK-2500 Copenhagen Valby \\ and
}

Institute of Genetics, University of Copenhagen, Øster Farimagsgade 2A, DK-1353 Copenhagen K.

Keywords: Lysine, chymotrypsin inhibitor 2, fluorescent labelling, fixation, mutants

\begin{abstract}
A screening method employing immunofluorescence has been developed to judge the amount of specific polypeptides, such as the high lysine protein chymotrypsin inhibitor 2 (Cl-2) in the endosperm of barley.

Thin sections or sanded seeds were prepared fixed in $4 \%$ paraformaldehyde and labelled with antibody against $\mathrm{Cl}-2$ conjugated with fluorescein isothiocyanate. With this technique single seeds can be evaluated without destroying their viability.

The deposition of $\mathrm{Cl}-2$ was followed during the grain development period in seeds of Hiproly and of the Hiproly sisterline (CI 4362) both by the immunofluorescence technique and by rocket immunoelectrophoresis. Accumulation of $\mathrm{CI}-2$ started about eight days later in $\mathrm{CI} 4362$ than in Hiproly. The demonstrable amounts of $\mathrm{Cl}-2$ in $\mathrm{Cl}$ 4362 were $20-25 \%$ of the amounts found in Hiproly.
\end{abstract}

\section{INTRODUCTION}

The seeds of cereal plants constitute a major source of energy and protein in the diet of man and domestic animals. The low content of essential amino acids such as lysine in the major storage proteins of cereal seeds, e.g. the hordeins in barley, limits their nutritional value. Theoretically protein quality could be improved by changing the relative composition of the seed proteins either by decreasing those poor in lysine or by increasing those rich in lysine.
The discovery of increased lysine levels in mutants in maize, originally selected by their altered opaque kernel phenotypes $(37,38,43)$, gave an impetus to search for improved protein quality in other cereals. By using the dye binding capacity analysis for basic amino acids combined with nitrogen analysis, at least eighteen mutants in barley have been identified in the past 15 years $(8,50)$. In sorghum the same techniques revealed that two opaque mutants had increased lysine contents (49). In all investi-

Abbreviations: $\mathrm{BSA}=$ bovine serum albumin; $\mathrm{Cl}-1$ = chymotrypsin inhibitor 1 ; CI-2 = chymotrypsin inhibitor 2; FITC = fluorescein isothiocyanate; $I g G=$ immunoglobulin $\mathrm{G} ; \mathrm{PBS}=$ phosphate buffer saline; SDS-PAGE = sodium dodecyl sulfate-polyacrylamide gel electrophoresis. 
gated mutants, the lysine increase is accompanied by $10-50 \%$ decreases in yield, which is not surprising given the insensitive nature of the screening technique employed.

In all cases studied, the major effects of the mutations have been confirmed by molecular studies at the polypeptide level. In barley the mutation hor-2ca (mutant Risø 56) specifically eliminates the $6-8$ unique $B$ hordein polypeptides $(9,46)$, the mutation lys $3 a$ (mutant Risø 1508) decreases synthesis of all hordein polypeptides coded for by the three genes Hor-1, Hor-2 and Hor-3 (4), while the mutation lysI (identified in Hiproly) increases synthesis of four albumin proteins, namely chymotrypsin inhibitor 1 and 2 (CI-1, Cl-2), protein-Z and $\beta$-amylase (22). In maize the opaque- 2 mutation seems analogous to hor-2ca in selectively decreasing the 22.5 $\mathrm{kD}$ zein class and the opaque-7 and floury-2 mutations to lys $3 a$ in generally inhibiting synthesis of all zein classes (5).

To find a commercially useful high lysine cereal, a screening technique capable of detecting changes in individual polypeptides is desirable. Today this should be feasible for any purified protein against which antibodies can be produced. By conjugating a fluorochrome to the antibody and then exposing the appropriate seed surface to the fluorescent antibody, the amount of the specified protein should be quantifiable. Herein the potential of the immunofluorescent approach to screen for new mutants is demonstrated for the lysine rich CI-2 protein in the endosperm of barley. This technique is far more rapid than techniques employed hitherto and has the additional advantage of not destroying the seed.

\section{MATERIALS AND METHODS}

\subsection{Plant material}

Seeds of Hiproly barley were from plants grown under standard conditions (10) in the Phytotron at the Swedish University of Agricultural Science, Stockholm in 1983. Seeds of the Hiproly sisterline, CI 4362, were from plants grown at the Carlsberg Research Farm, Hyldagergård, in the summer of 1981 . The genotypes of the seeds were confirmed by a radial immuno- diffusion test (30). A description of Hiproly and CI 4362 can be found in $(40,41)$.

For analysis of $\mathrm{Cl}-2$ deposition during the grain filling period, spikes were collected from Hiproly and CI 4362 plants grown at Hyldagergård in 1984. At 14, 18, 22, 26, 30 and 44 days after anthesis ten spikes were harvested, frozen in liquid $\mathrm{N}_{2}$ and stored at $-20^{\circ} \mathrm{C}$.

\subsection{Chemicals}

Sephadex G-25 and Protein-A coupled Sepharose were from Pharmacia Fine Chemicals, Uppsala, Sweden. Diethylaminoethyl (DEAE)cellulose type DE-52 was from Whatman, Maidstone, England. Bovine serum albumin (BSA) was obtained from Sigma Chemical, St. Louis, Missouri, USA. Fluorescein isothiocyanate (FITC) was from Research Organic, Cleveland, Ohio, USA. Rabbit antimouse immunoglobulin, IgG (control serum) was obtained from DAKO, Copenhagen, Denmark. Paraformaldehyde analytical grade was from Merck, Darmstad, Germany.

\subsection{Fixation and sectioning of tissue}

Half seeds sectioned by a dorsoventral longitudinal cut were fixed by imbibition in the paraformaldehyde-lysine-periodate fixative detailed by MCLEAN (36) as described by GIBBONS (14).

Seeds were embedded in Tissue Tek II, embedding medium for frozen tissue specimens, (Miles Laboratories, Naperville, Illinois, USA) and $12 \mu \mathrm{m}$ sections were cut on a Reichert Jung Frigocut 2700 Cryotome (Jung, Heidelberg, Germany). The sections were transferred to moist $1 \%$ gelatine-coated slides.

For surface fixation the seeds were embedded in a Cernit-plate (23), and sanded obliquely with a sanding-machine without damaging the embryos. A $4 \%$ solution of paraformaldehyde was applied to the sanded surface of the seed with a paint brush. After two hours at $5{ }^{\circ} \mathrm{C}$ the seeds were washed for $30 \mathrm{~min}$ by immersion in phosphate buffer saline, PBS (10 mM-sodium phosphate containing $150 \mathrm{~mm}$-sodium chloride at $\mathrm{pH}$ 7.3). 


\subsection{Rocket immunoelectrophoresis}

The extraction of $\mathrm{CI}-2$ was performed as described by JONASSEN (30). Five $\mu 1$ of each extract was placed in a well of a $1 \%$ agarose gel. The electrophoresis buffer was $73 \mathrm{~mm}$-Tris, 24.3 $\mathrm{mM}$-barbital, $0.34 \mathrm{~mm}$-calcium lactate, $\mathrm{pH} 8.6$. The agarose gel contained $16 \mu \mathrm{Cl}-2$ rabbit antiserum per $\mathrm{ml}$ gel. Rocket immuno electrophoresis was run at $2.5 \mathrm{~V} / \mathrm{cm}$ for 18 hours, and the protein precipitations visualized by staining with Coomassie blue R-250.

\subsection{Test of serum and purification of $\mathbf{I g G}$}

Rabbit antiserum, prepared against purified $\mathrm{CI}-2$ (28) was obtained from DAKO. The antiserum was previously tested for monospecificity by crossed immunoelectrophoresis with a 5 times concentrated crude Hiproly extract (28) and by an immune-blotting assay (25) imploying purified $\mathrm{CI}-2$ and crude Hiproly extract. A single band at identical positions was obtained in both cases. Purification was accomplished by Protein-A Sepharose affinity chromatography according to the manufacturer's directions.

\subsection{Conjugation of FITC to purified IgG}

The conjugation between FITC and IgG was performed according to (33). The FITC-IgG conjugate was separated from free FITC by gel filtration on a Sephadex G-25 column. The conjugate was then chromatographed on a DEAE-cellulose column to remove under and over conjugated $\mathrm{IgG}$. The absorbances at 280 $\mathrm{nm}$ and $495 \mathrm{~nm}$ were recorded on a spectrophotometer (Shimadzu, UV-120-12, Japan). The protein concentration was determined (54) and the FITC/protein ratio calculated (52). Fractions with a FITC/protein ratio between two to five were pooled and stored at $4{ }^{\circ} \mathrm{C}$ in 15 mM-sodium azide.

\subsection{Immunohistochemistry}

\subsubsection{Immunolabelling on thin sections}

The seed sections were washed with PBS for 30 min by immersion. One drop corresponding to $30 \mu \mathrm{l}$ PBS containing 1\% BSA was applied to each section. To retain a uniform concentration of antibody the solution was removed after 15 min, and reapplied and the section left for a further $15 \mathrm{~min}$. Following removal of the BSA solution, $30 \mu \mathrm{FITC}$ coupled rabbit anti $\mathrm{CI}-2$ $\left(0.7 \mathrm{mg} \cdot \mathrm{ml}^{-1}\right)$ or control serum was applied and the incubation procedure repeated. The sections were washed by dipping in distilled water and then immersing in PBS for $15 \mathrm{~min}$. They were then mounted in glycerol, adjusted to $\mathrm{pH} 7.4$ with sodium phosphate buffer, stored in the dark at $4{ }^{\circ} \mathrm{C}$ and analysed within 24 hours.

\subsubsection{Immunolabelling on surface fixed seeds}

The surface of the Cernit block containing the partly embedded and sanded seeds was covered with PBS for $30 \mathrm{~min}$. The inverted block was placed in a $6 \mathrm{ml}$ box completely filled with $10 \%$ BSA in PBS, and the exposed seed surface washed by mechanical shaking for $30 \mathrm{~min}$. The same procedure was then used to incubate with FITC labelled anti Cl-2 $\left(0.7 \mathrm{mg} \cdot \mathrm{ml}^{-1}\right)$ for $20 \mathrm{~min}$ and then to wash four times with PBS. The block was stored at $4{ }^{\circ} \mathrm{C}$ in the dark for one hour before analysis.

\subsection{Fluorescence microscopy}

A Reichert Univar microscope (Reichert, Vienna, Austria), fitted with a $200 \mathrm{~W}$ DC mercury lamp (Illumination Industries Inc., Sunnyvale, California) was used. Excitation filters, dichroic mirrors and emission filters were from Optisk Laboratorium (Lundtofte, Denmark) and had the following characteristics: Excitation filters had a band pass BP 450-495 nm (used for the illustrations in Figures 3, 4, 5 and 6) or BP 420-500 nm (used for Figure 1). The emission filter had a beam splitter BS $510 \mathrm{~nm}$ and a long wave pass LWP $515 \mathrm{~nm}$. All photographs were taken on Kodak Ektachrome 400 film (Kodak, Rochester, N.Y., USA).

The fluorescence analyses were carried out with a Jasco FP-550 scanning spectrofluorometer (Japan Spectroscopy Co.) equipped with a Perkin-Elmer thin layer chromatography fluorescence scanner (Perkin-Elmer, Connecticut, USA). The measurements were performed with an excitation wavelength of $495 \mathrm{~nm}$ and an emission wavelength of $520 \mathrm{~nm}$. 


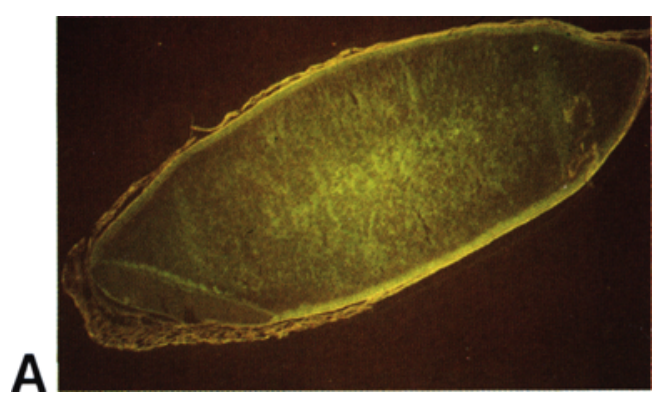

$2 \%$

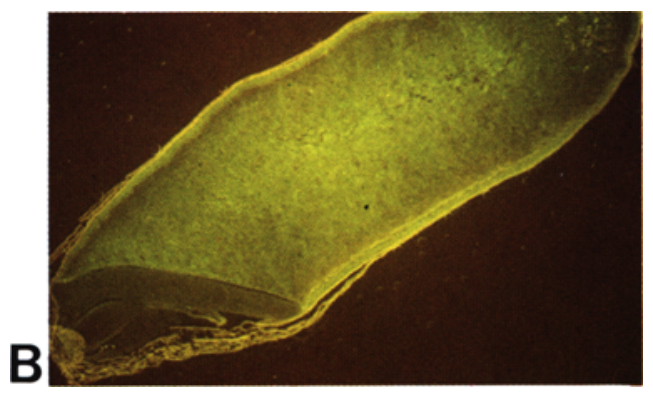

$4 \%$

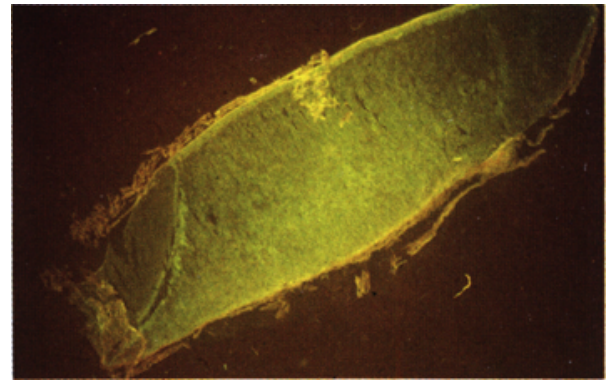

$4 \%$

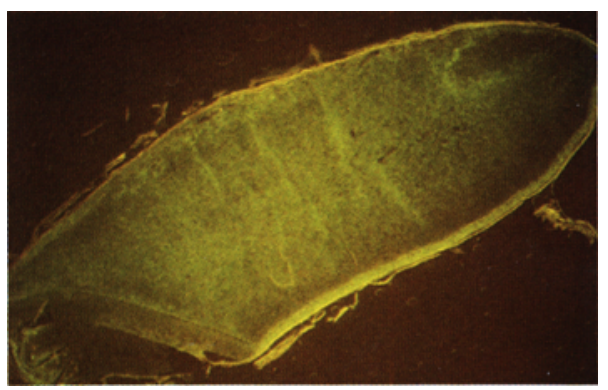

$10 \%$

Figure 1. The concentration of paraformaldehyde used for fixation affects the immunofluorescence arising from subsequent treatment with FITC-immunolabelled Cl-2.

Two Hiproly barley seeds (A and B) were cut into halves and fixed with paraformaldehyde solutions of the indicated strengths. Thin sections were made with a cryomicrotome and treated with FITC labelled anti $\mathrm{Cl}-2$ as described in section 2.3 and 2.7.1.

\section{RESULTS}

\subsection{The influence of paraformaldehyde}

fixation on the in situ immunofluorescence of FITC-labelled CI-2

Fixation of seeds using paraformaldehyde was chosen as the starting point of this investigation because paraformaldehyde causes a minimum loss in antigenicity of the proteins compared to other fixatives $(7,13,51)$. The fixation was carried out for 15 hours (14).

To determine if the level of fluorescence would be affected by the paraformaldehyde fixation parameters, half seeds were incubated in 2,4 , and $10 \%$ paraformaldehyde solutions for 15 hours. After immunolabelling of $\mathrm{CI}-2$ in the sectioned seed, the resulting fluorescence was examined by microscopy (Figure 1). In both cases the fluorescence was strongest when the fixation was performed in a $4 \%$ para- formaldehyde solution. Another fixation series was carried out with 3,4 , and $6 \%$ paraformaldehyde solutions. The fluorescence of the 3,4 and $6 \%$ treated samples was similar. On the basis of these observations use of $4 \%$ paraformaldehyde solutions for fixation was chosen, as it represents the center of the plateau resulting in maximal fluorescence.

The amount of fluorescence can be quantified by use of a scanning spectrofluorometer as shown in Figure 2. Clear differences occur between three seeds with high CI-2 and three seeds with low Cl-2.

\subsection{Origin of fluorescence after treating sections of fixed seeds with FITC-labelled anti $\mathrm{CI}-2$}

As shown in Figure 3C autofluorescence of seed sections is not detectable at the excitation 


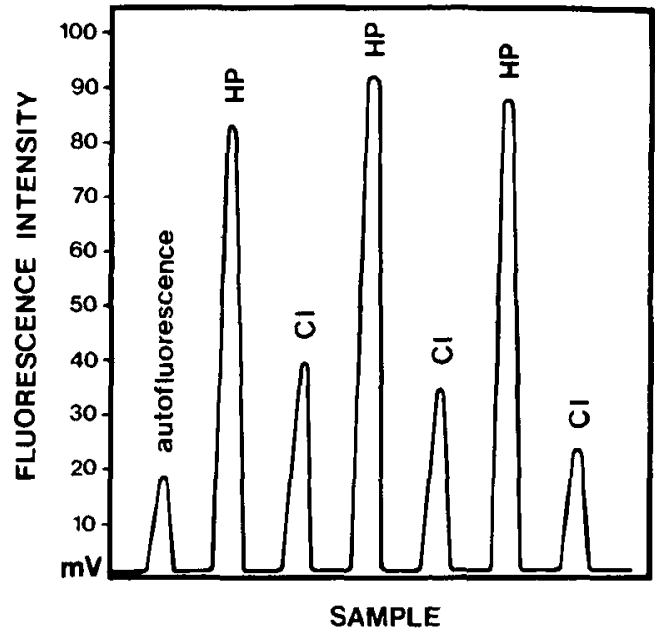

Figure 2. Semiautomatic classification of Hiproly (HP) and $\mathrm{CI} 4362(\mathrm{CI})$ seeds with high and low $\mathrm{CI}-2$ contents, respectively, using FITC-immunolabelled sections.

Sections were mounted on a microscope slide and scanned at $520 \mathrm{~nm}$.

wavelength of $495 \mathrm{~nm}$ used when examining the seeds. The FITC-labelled preparation against $\mathrm{Cl}-2$ was subjected to a double diffusion analysis according to OUCHTERLONY (45) with purified CI-2. The immune-blotting assay with extracted Hiproly proteins and purified $\mathrm{Cl}-2$ separated in adjacent lanes by SDS-PAGE yielded the same single band and confirmed the specifity of the antibody. To ensure that only FITC-labelled antibodies to $\mathrm{CI}-2$ were contributing to the fluorescence, seed sections were treated with a control IgG preparation. The latter was obtained by an identical procedure as the FITC-labelled anti Cl-2 preparation. As shown in Figure $2 \mathrm{~B}$ no Hiproly endosperm proteins reacted with the control preparation.

\subsection{Comparison between the} immunofluorescence and the radial immunodiffusion tests for detection of CI2 in individual barley seeds

Twenty seeds of Hiproly and twenty seeds of CI 4362 were cut into halves. One half of each seed was fixed in a $4 \%$ paraformaldehyde solution, sectioned and treated with FITC-labelled anti CI-2 followed by a visual evaluation of the
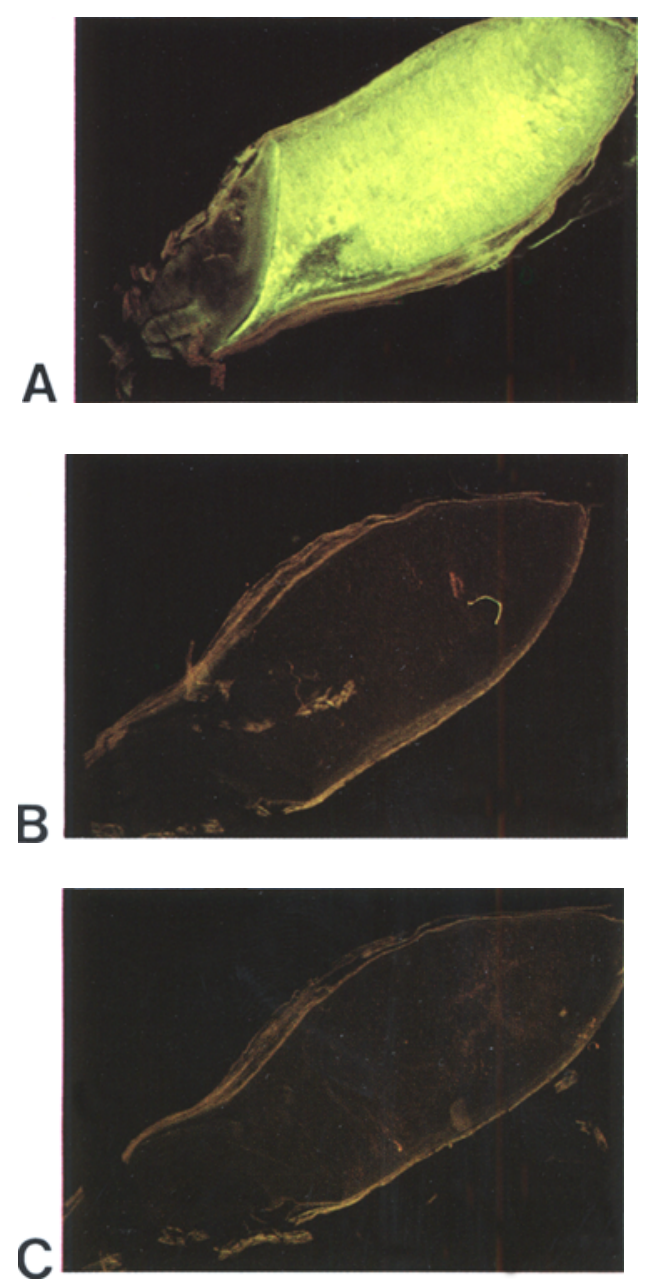

Figure 3. Examination of the specificity of the immunofluorescence.

Intact mature Hiproly barley seeds were fixed in a 4\% paraformaldehyde solution for 15 hours. Thin sections were cut therefrom and reacted with (A) FITC-labelled anti CI- 2 or (B) control serum (sections 2.3 and 2.7.1). (C) shows that no autofluorescence occurs at the $495 \mathrm{~nm}$ excitation wavelength used.

resulting fluorescence. Using a previously described technique (30), Cl-2 was extracted from the other half of each seed and subjected to the radial imunodiffusion test. In 19 of the 20 Hiproly seeds, both techniques revealed a high content of CI-2 (Figure 4) which was expected for this barley variety. Likewise in 19 of the $20 \mathrm{CI}$ 4362 seeds both techniques revealed low con- 


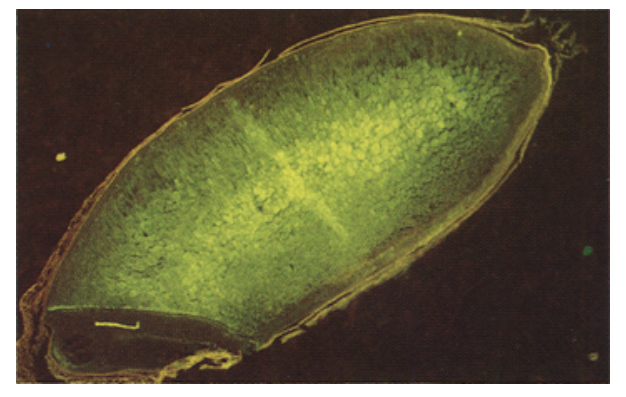

\section{HIPROLY}

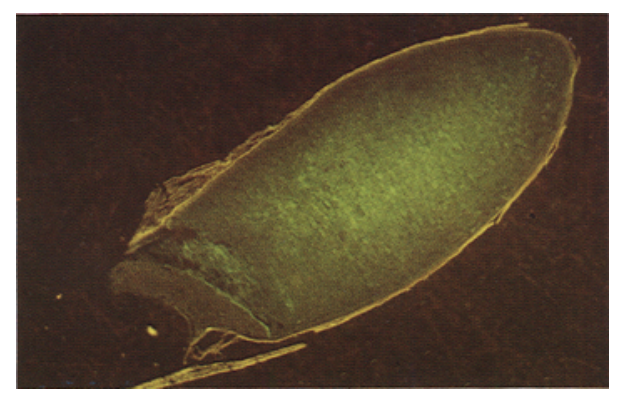

\section{4362}

Figure 4. Comparison of the in situ immunofluorescence technique with the radial immunodiffusion test.

Barley seeds with high (HIPROLY) and low (CI 4362 ) contents of $\mathrm{Cl}-2$ were cut into halves. The upper half was fixed with $4 \%$ paraformaldehyde, sectioned and treated with FITC-labelled anti CI-2 (sections 2.3 and 2.7.1) before inspection in the fluorescence microscope. The proteins from the lower half were extracted, and the CI-2 content assayed by the radial immunodiffusion test (30).

tents of CI-2 (Figure 4). The failure of the other two seeds to fall into the expected categories supports the conclusion that the variety Hiproly and its sisterline CI 4362 are not totally homogeneous (40). On the basis of the present observations it appears that the immunofluorescence technique is as good as the radial immunodiffu- sion test for detection and quantification of $\mathrm{Cl}-2$ in seeds.

\subsection{Deposition of CI-2 during seed devel- opment}

Spikes of Hiproly and CI 4362 were harvested $14,18,22,26,30$ and 44 days after anthesis. Two neighbouring seeds from each spike (number three from base) were analysed for CI-2 content by immunolabelling on thin sections (Figure $5 \mathrm{~A}$ ), by rocket immunoelectrophoresis of endosperm extracts (Figure 5B) and also by a radial immunodiffusion test. By including standards in the two latter analyses, the amount of CI-2 was quantified $(2,29)$. CI- 2 is detectable from day 18 in Hiproly endosperms, whereas it is not until day 26 in CI 4362 endosperms. Thereafter, increasing amounts are present in both genotypes during grain filling. From the time $\mathrm{CI}-2$ was detectable in CI 4362 until maturity the amount ranged from $20-25 \%$ of that found in Hiproly. To illustrate, at harvest Hiproly contained 2.8-3.9 $\mu \mathrm{g} \mathrm{CI}-2$ per dry matter of seeds as compared to $0.7 \mu \mathrm{g}$ of $\mathrm{CI}-2$ in CI 4362 . These results are in accordance with and extend earlier observations (29).

\subsection{Non-destructive immunofluorescent detection of CI-2 in seeds}

The results reported hitherto are all based on immunochemical reactions taking place on the surface of a seed section cut on a cryomicrotome, a technique which destroys the seed. To determine if the described immunofluorescence technique could be applied to seeds in a non-destructive fashion, the seed fixation system developed by HELTVED et al. (23) was used. Hiproly and CI 4362 seeds were embedded in clay blocks (Cernite), and $1 \mathrm{~mm}$ of the dorsal side of the seed was removed by sanding to expose the endosperm without affecting the germ. The exposed endosperm surfaces were then painted with $4 \%$ paraformaldehyde and after two hours washed and treated with anti CI-2, as described in section 2.7.2. First, the viability of 100 seeds of each genotype handled in this fashion was tested by germinating them on wet filter paper. The viability as assayed by percent germination after 1,2 

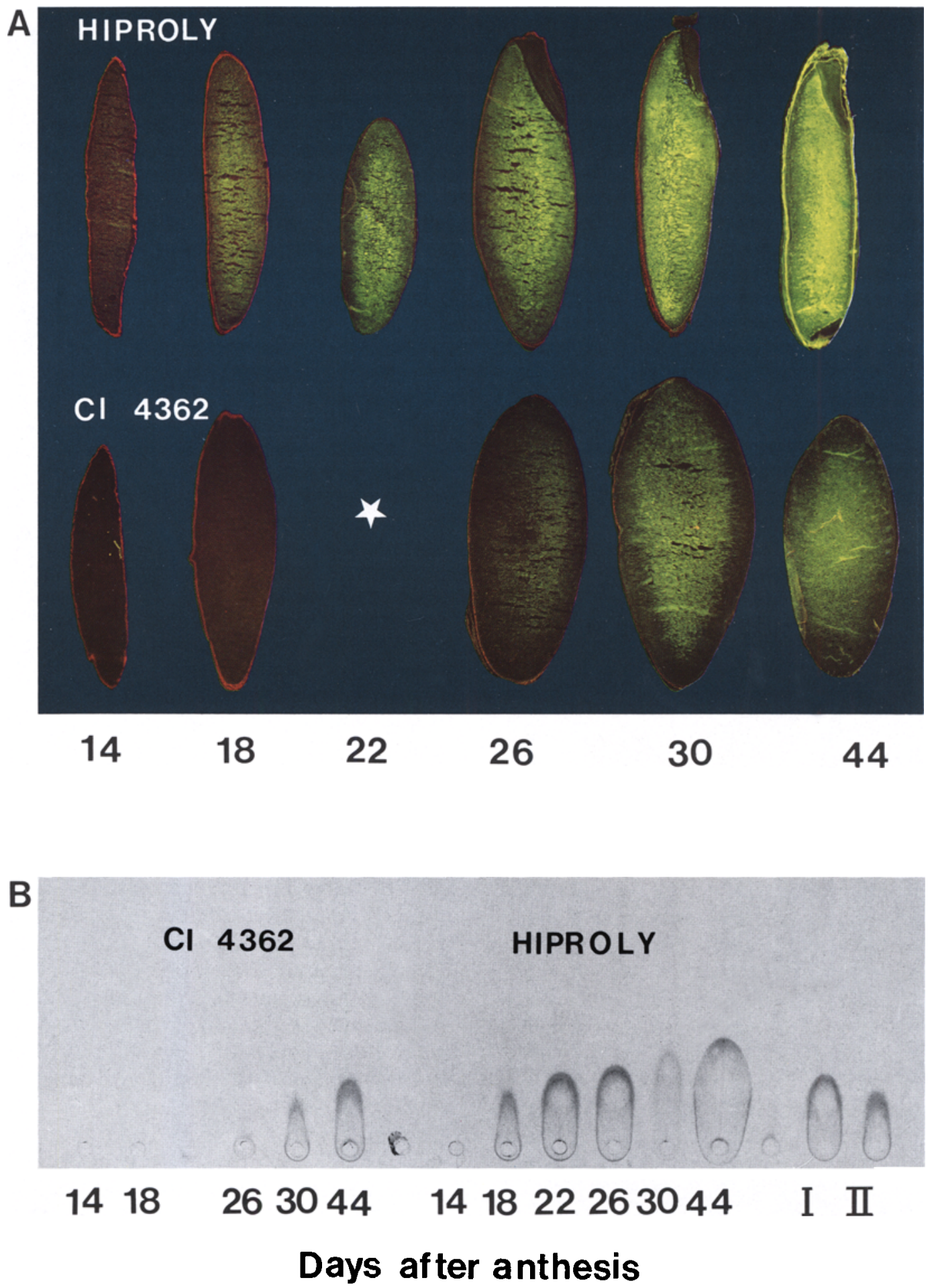

Figure 5. Synthesis of CI-2 in developing endosperms of Hiproly and CI 4362.

Two seeds were selected from spikes harvested at 14,18,22,26, 30 and 44 days after pollination. (A) One seed from each spike was fixed, sectioned and treated with FITC labelled anti Cl-2 (sections 2.3 and 2.7.1). (B) A seed from each spike was analysed for its content of $\mathrm{Cl}-2$ by rocket immunoelectrophoresis (section 2.4). I $=0.625 \mu \mathrm{g} \mathrm{Cl}-2$. II $=0.312 \mu \mathrm{g} \mathrm{CI}-2 .{ }^{*}=$ not analysed. 

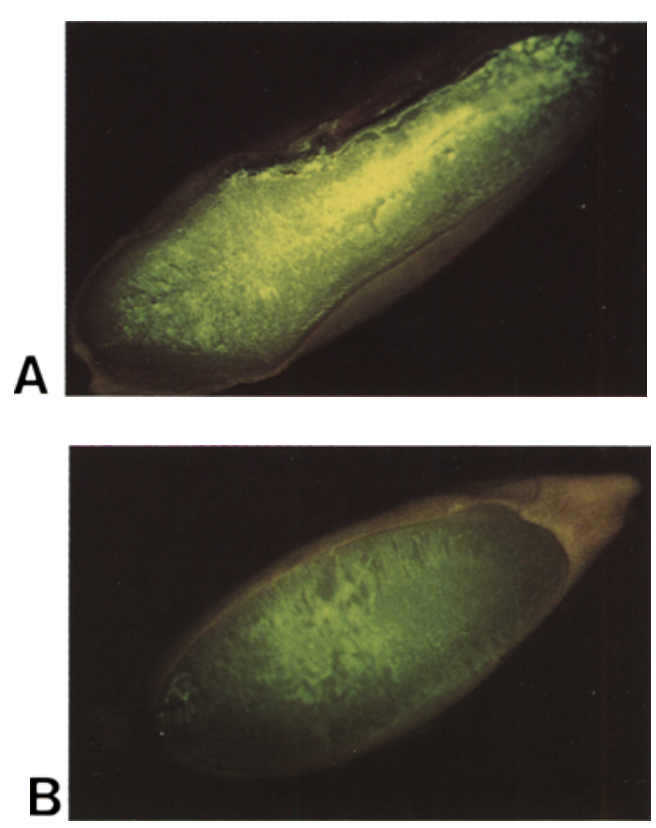

Figure 6. Detection of $\mathrm{Cl}-2$ proteins in mature barley seeds.

One $\mathrm{mm}$ of the outer layer of the endosperm was removed by sanding. The exposed surface was fixed with $4 \%$ paraformaldehyde and then treated with FITC labelled anti $\mathrm{Cl}-2$ before visualization in the fluorescence microscope (sections 2.3 and 2.8). (A) Hiproly, (B) $\mathrm{Cl} 4362$.

and 3 hours incubation was 100,100 , and $70 \%$, respectively. Next, 32 Hiproly and 32 CI 4362 seeds were analysed with the immunofluorescent assay for CI-2. In 29 of the 32 Hiproly seeds a high content of CI- 2 was observed. Likewise, in 28 of the $32 \mathrm{CI} 4362$ seeds a low content of CI-2 was revealed. The failure of the seven seeds to show the expected amounts of $\mathrm{Cl}-2$ is presumably' due to the same inhomogeneity mentioned in section 3.3. Figure 6 presents Hiproly and CI 4362 seeds illustrating the obtained difference in fluorescence.

\section{DISCUSSION}

The high-lysine character of Hiproly barley results from an increased content of specific lysine-rich proteins attributed to the presence of the recessive gene, lys (42), located on chromosome 7 (32). Four lysine-rich, salt soluble proteins in the endosperm of kernels have been identified, protein- $Z$ (21), $\beta$-amylase and two chymotrypsin inhibitors $\mathrm{CI}-1$ and $\mathrm{CI}-2(3,22)$. Hiproly barley contains twenty-fold higher amounts of CI- 1 and CI- 2 than normal cultivated varieties (3). The elevated content of $\mathrm{CI}-2$ in Hiproly accounts for $37 \%$ of the difference in lysine content between Bomi and Hiproly and for $19 \%$ between its low lysine sisterline, CI 4362 and Hiproly (29). To identify new high-lysine genotypes several chemical screening methods have been developed $(1,50)$ which unfortunately are relatively time consuming. Therefore, establishment of a simple and rapid procedure to pick out changes in the amount of individual proteins is desirable. As a first step toward this goal, the present paper describes a non-destructive screening method based on in situ immunolabelling of seeds with antibody prepared against $\mathrm{CI}-2$.

Since the introduction of the fluorescent antibody technique by CoONS et al. (6), the use of this technique to detect and visualize specific antigens has become a commonly employed technique in biology and medicine (11). In plants immunofluorescence has been used for example to detect the cellular localisation of ribulose-1,5-bisphosphate carboxylase in leaves (20) and guard cells (34), of coniferin in spruce seedlings (35), of cellulase in beans (47), of wheat germ agglutinin in wheat embryos and wheat plants (39) and of a presumptive auxin transport carrier in pea stem cells (26) and for localization of $\beta$-amylase in germinating rice seeds (44). The technique has also been used for localization of $\alpha$-amylase in barley aleuron tissue $(27,31)$ and to follow the transport of $\alpha$-amylase in germinating barley seeds $(13,14,15)$.

The sensitivity of detection of proteins by the immunolabelling technique depends mainly upon the preservation of the intact antigenic sites of the antigen during tissue processing. Fixation of plant tissue is often performed in paraformaldehyde or glutaraldehyde solutions of different concentrations. Use of paraformaldehyde instead of glutaraldehyde reduces the loss in antigenicity $(7,51)$. Another reason for choosing paraformaldehyde is that less nonspecific binding takes place than with glutaraldehyde (48). The optimum concentration of the 
fixative varies from antigen to antigen. For $\alpha$-amylase a $10 \%$ paraformaldehyde fixation gave the best result (13), whereas in this study the optimum concentration for fixation of $\mathrm{Cl}-2$ was 3-6\% paraformaldehyde.

A potential source of error in the fluorescence technique is non-specific binding of the antibody $(7,19,24)$, purity of the fluorochrome and the quality of the labelled antibody preparations used $(12,18,54)$. If too many fluorochromes are coupled to each $\mathrm{lgG}$ the staining is brilliant, but an increase in non-specific staining may occur, whereas if too few fluorochromes are coupled, the conjugated molecule does not emit sufficient light to be well visualized. Since the variation in the number of fluorochromes coupled to the antibody results in compounds of different charge they can be separated from one another using a DEAE-cellulose column. Immunolabelling experiments $(12,18)$ with each fraction eluted from the column revealed that a ratio of two to five molecules of FITC to each molecule of antibody gives a bright specific stain with a negligible background stain. FITC was chosen as the fluorochrome in this study as it is easily conjugated to proteins. Despite the fact that its fluorescence colour does not contrast well with the low yellow-brown autofluorescence of the endosperm, this did not prohibit its use in the present study. For thin section conditions autofluorescence was essentially non-existent, while for surface fixed seeds the contrast between specific binding and background was within satisfactory limits.

Having optimized the parameters affecting the sensitivity of detection of the immunolabelling of CI-2 in seeds, the technique was then compared with the radial immunodiffusion test and found to give equivalent results. The immunofluorescence method for screening seeds is superior, however, since whole seeds can be analyzed in a non-destructive fashion. The potential also exists for screening a large number of seeds within one day. The latter is of a great importance as even with the use of sodium azide the mutation frequency for specific traits in barley is only $.003 \%(53)$. It is estimated that of the mutants isolated only one in every 200 300 will not show a decrease in yield (53). This technique may also apply to the selection of recombinants in conventional cross breeding programs directed at improving yield by providing a different genetic background for the identified deleterious mutants. The immunofluorescence technique is not limited to the $\mathrm{CI}-2$ protein but can be applied to all seed proteins for which specific antibodies can be produced. Should monoclonal antibodies be available even minor alterations in the primary structure of a specified protein may be detectable.

The synthesis and deposition of different saltsoluble proteins in the endosperm of developing barley grains have been investigated. Specifically, the accumulation patterns of protein $Z$, $\beta$-amylase and hordein have been analysed by separation of proteins by SDS-PAGE $(16,17)$. The three proteins are detectable early in development, about 10 days after anthesis, and increase during development. In the study reported here the accumulation of $\mathrm{CI}-2$ was followed by the immunofluorescence technique on thin sections and by rocket immunoelectrophoresis. In Hiproly CI-2 accumulated in the endosperm during the entire grain filling period, in CI 4362 the deposition took place in the latter part of the grain filling, starting at day 26 . Thus accumulation takes place over only 18 days instead of 26 days as in Hiproly, which is equivalent to a reduction in time of synthesis by $31 \%$. These observations suggest that the difference between Hiproly and Hiproly sisterline is the result of a differential modification of a regulatory gene determining the onset of CI-2 synthesis. Since the methods used would not detect amounts of CI-2 less than that measured at 26 days, this hypothesis must be regarded as speculative.

\section{ACKNOWLEDGEMENTS}

I would like to thank Dr. L. MUNCK, Dr. P. VON WETTSTEIN-KNOWLES and Dr. J. INGVERSEN for critical reading and reviewing the manuscript. Thanks are due to Dr. G. HøYER-HANSEN and Dr. J. MUNDY for expert advice concerning immunology and fluorescence, respectively. M. HøJ and N. RASMUSSEN are acknowledged for their technical assistance, and the personnel of the Phytotron in Stockholm and at Hyldagergård in Denmark are thanked for growing the plants. 


\section{REFERENCES}

1. AHokas, $\mathbf{H}$.: A simple and inexpenisve visual method for distinguishing between high-lysine and normal-lysine barley kernels. Cereal Chem. 60, 330-331 (1983)

2. Axelsen, N.H., J. Krøll \& B. WeEk: A manual of quantitative immunoelectrophoresis. Methods and applications. Universitetsforlaget Oslo (1973)

3. Boisen, S., C. Yding ANDERSEn \& J. HejgaARD: Inhibitors of chymotrypsin and microbial serine proteases in barley grains. Physiol. Plant. 52, 167176 (1981)

4. BRANDT, A.: Endosperm protein formation during kernel development of wild type and a high-lysine barley mutant. Cereal Chem. 53, 890-901 (1976)

5. BURR, F.A. \& B. BURR: Three mutations in Zea mays affecting zein accumulation: a comparison of zein polypeptides, in vitro synthesis and processing, mRNA levels, and genomic organization. $\mathbf{J}$. Cell Biol. 94, 201-206 (1982)

6. CoOns, A.H., H.J. CReEch, R.N. Jones \& E. BerLINER: The demonstration of pneumococcal antigen in tissue by the use of fluorescent antibody. J. Immunol. 45, 159-170 (1942)

7. Craig, S. \& D.J.GoodChILD: Post-embedding immunolabelling. Some effects of tissue preparation on the antigenicity of plant proteins. Eur. J. Cell Biol. 28, 251-256 (1982)

8. Doll, H.: Genetic studies of high lysine barley mutants. In: Barley Genetics III (Ed. H. Gaul), Karl Thiemig Verlag, Munchen, pp. 542-546 (1975)

9. Doll, $H$ : : A nearly non-functional mutant allele of the storage protein locus Hor 2 in barley. Hereditas 93, 217-222 (1980)

10. Dormling, I., A. Gustafsson \& D. von WettSTEIN: Phytotron cultivation of Bonus barley: The control of maturation and grain quality. Hereditas 63, 415-428 (1969)

11. Feteanu, A.: Labelled antibodies in biology and medicine. Abacus Verlag, Tunbredge Wells (1978)

12. Fuitwara, K. \& T.D. Pollard: Fluorescent antibody localization of myosin in the cytoplasma, cleavage furrow, and mitotic spindle of human cells. J. Cell Biol. 71, 848-875 (1976)

13. GibBons, G.C.: On the localisation and transport of $\alpha$-amylase during germination and early seedling growth of Hordeum vulgare. Carlsberg Res. Commun. 44, 353-366 (1979)

14. GibBons, G.C.: Immunohistochemical determination of the transport pathways of $\alpha$-amylase in germinating barley seeds. Carlsberg Res. Commun. 8, 87-96 (1980)

15. GibBons, G.C.: On the sequential determination of $\alpha$-amylase transport and cell wall breakdown in germinating seeds of Hordeum vulgare. Carlsberg Res. Commun. 45, 177-184 (1980)

16. Giese, H., B. ANDERSEN \& H. Doll: Synthesis of the major storage protein, hordein, in barley. Pulse-labeling study of grain filling in liquid-cultured detached spikes. Planta 159, 60-65 (1983)

17. Giese, H. \& J. HejgaARd: Synthesis of salt-soluble proteins in barley. Pulse-labeling study of grain filling in liquid-cultured detached spikes. Planta 161, 172-177 (1984)

18. Goldstein, G., B.H. Spanding \& W.B. Hunt: Studies on fluorescent antibody staining II. Inhibition by sub-optimally conjugated antibody globulins. Proc. Soc. Exp. Biol. Med. 11, 416-421 (1962)

19. Grube, D.: Immunoreactivities of gastrin (G-) cells. II. Non-specific binding of immunoglobulins to G-cells by ionic interactions. Histochem. 66 , 149-167 (1980)

20. Hattersley, P.W., L. Watson \& C.B. Osmond: In situ immunofluorescent labelling of ribulose1,5-bisphosphate carboxylase in leaves of $\mathrm{C}_{3}$ and C $_{4}$ plants. Aust. J. Plant Physiol. 4, 523-539 (1977)

21. Hejgatard, $\mathbf{J}$.: Purification and properties of protein $Z$ - a major albumin of barley endosperm. Physiol. Plant. 54, 174-182 (1982)

22. HejGaARD, J. \& S. BoISEN: High-lysine proteins in Hiproly barley breeding: Identification, nutritional significance and new screening methods. Hereditas 93, 311-320 (1980)

23. Heltved, F., S. Aastrup, O. Jensen, G. Gibbons \& L. MUNCK: Preparation of seeds for mass screening. Carlsberg Res. Commun. 47, 291-296 (1982)

24. Herbert, G.A., B. Pittman \& W.B. Cherry: Factors affecting the degree of nonspecific staining given by fluorescein isothiocyanate labeled globulins. J. Immunol. 98, 1204-1212 (1967)

25. Høyer-HANSEN, G.: Monoclonal antibody to chlorophyll a-protein 1 in barley. In: Advances in Photosynthesis Research. C. Sybesma ed., M. Nijhoff/ Dr. W. Junk Publishers, The Hague, The Netherlands Vol III 171-174 (1984)

26. JACOBS M. \& S.F. GILBERT: Basal localization of the presumptive auxin transport carrier in pea stem cells. Science 220, 1297-1300 (1983)

27. JACOBSEN, J.V. \& R.B. KNoX: Cytochemical localization and antigenicity of $\alpha$-amylase in barley aleuron tissue. Planta 112, 213-224 (1973)

28. JoNASSEN, I.: Characteristics of Hiproly barley I. Isolation and characterisation of two water-soluble high-lysine proteins. Carlsberg Res. Commun. 45, 47-58 (1980)

29. JONASSEN, I.: Characteristics of Hiproly barley II. Quantification of two proteins contributing to its high lysine content. Carlsberg Res. Commun. 45. 
$59-68(1980)$

30. JONASSEN, I.: Segregation of high and low chymotrypsin inhibitor $\mathrm{Cl}-2$ content in crosses between Hiproly and normal lysine barley genotypes. Carlsberg Res. Commun. 47, 305-312 (1982)

31. JONES, R.L. \& RU-FANG CHEN: Immunohistochemical localization of $\alpha$-amylase in barley aleuron cells. J. Cell Sci. 20, 183-198 (1976)

32. KARLSSON, K.E.: Linkage studies on the $L y s$-gene in relation to some marker genes and translocations. In: Barley Genetics III (Ed. H. Gaul), Karl Thiemig Verlag, Munchen, pp. 536-541 (1975)

33. Laboratory Manual: Hybridomas and monoclonal antibodies. Organized by Z. Eshhar. Weismann Institute of Science, Rehovert 76100, pp. 63-64 Israel (1982)

34. MadHAven, S. \& B.N. Smith: Localization of ribulose bisphosphate carboxylase in the guard cells by an indirect, immunofluorescence technique. Plant Physiol. 69, 273-277 (1982)

35. Marcinowski, S., H. FalK, D.K. Hammer, B. HOYER \& H. GRISEBACH: Appearence and localization of a $\beta$-glucosidase hydrolyzing coniferin in spruce (Picea abies) seedlings. Planta 144, 161-165 (1979)

36. McLean, 1.W. \& P.K. NaKane: Periodate-lysineparaformaldehyde fixative. A new fixative for immunoelectron microscopy. J. Histochem. Cytochem. 22, 1077-1083 (1974)

37. Mertz, E.T. \& L.S. Bates: Mutant gene that changes protein composition and increases lysine content of maize endosperm. Science 145, 279-280 (1964)

38. MisRa, P.S., R. Jambunathan, E.T. Mertz, D.V. GLOVER, H.M. BARBOSA \& K.S. MCWHIRTER: Endosperm protein synthesis in maize mutants with increased lysine content. Science 176, 1425-1427 (1972)

39. Mishikind, M.L., B. A. PaleVitz \& N.V. Raikhel: Localization of wheat germ agglutinin-like lectins in various species of the gramineae. Science 220 , 1290-129,2 (1983)

40. MUNCK, L.: Improvement of nutritional value in cereals. Hereditas 72, 1-128 (1972)

41. MunCK, L: High lysine barley - a summary of present research development in Sweden. Barley Genet. Newsletter 2, 54-59 (1972)

42. Munck, L., K.E. Karlsson, A. Hagberg \& B.O. EGGUM: Gene for improved nutritional value in barley seed protein. Science 168, 985-987 (1970)
43. Nelson, O.E., E.T. MerTZ \& L.S. Bates: Second mutant gene affecting the amino acid pattern of maize endosperm proteins. Science 150, 14691470 (1965)

44. OKamoto, K. \& T. AKazawa: Enzymic mechanism of starch breakdown in germinating rice seeds. Plant Physiol. 64, 337-340 (1979)

45. OUCHTERLONY, O. \& L.A. NiLSSON: Immunodiffusion and immunoelectrophoresis. In: Handbook of Experimental Immunology, 3rd edn (Ed. D.M. Weir), Blanckwell Scientific Publ., Oxford, pp. 19.1-19.44 (1978)

46. Rasmussen, S.K., H.E. Hopp \& A. Brandt: Nucleotide sequences of $\mathrm{CDNA}$ clones for $\mathrm{B} 1$ hordein polypeptides. Carlsberg Res. Commun. 48, 187199 (1983)

47. Sexton, R., M.L. Durbin, L.N. Lewis \& W.W. THOMSON: The immunocytochemical localization of 9.5 cellulase in abscission zones of bean (Phaseolus vulgaris cv. red kidney). Protoplasma 109, 335-347 (1981)

48. Shumway, L.K., V.V. Yang \& C.A. Ryan: Evidence for the presence of proteinase inhibitor $I$ in vacuolar protein bodies of plant cells. Planta 129, 161-165 (1976)

49. SiNGH, R. \& J.D. AxtelL: High lysine mutant gene $(h l)$ that improves protein quality and biological value of grain sorghum. Crop Sci. 13, 535-539 (1973)

50. TALlberg, A.: Characterization of high-lysine barley genotypes. Hereditas 96, 229-245 (1982)

51. Tokuyasu, K. T. \& S.J. Singer: Improved procedures for immunoferritin labeling of ultrathin frozen sections. J. Cell Biol. 71, 894-906 (1976)

52. Wells A.F., C.E. MilleR \& M.K. NAdel: Rapid fluorescein and protein assay method for fluorescent-antibody conjugates. Appl. Microbiol. 14, 271-275 (1966)

53. Wettstein, D. von., R.A. Nilan, B. AhrenstLarsen, K. ERdal, J. IngVersen, B. JendeStrid, K.N. Kristiansen, J. Larsen, H. OutTRUP \& S.E. ULLRICH: Proanthocyanidin-free barley for brewing: Progress in breeding for high yield and research tool in polyphenol chemistry. MBAA Tech. Quarterly. 22, in press

54. WOOD, B.T., S.H. ThOMPSON \& G. GoldsteIN: Fluorescent antibody staining III. Preparation of fluorescein-isothiocyanate-labeled antibodies. J. Immunol. 95, 225-229 (1965)

Accepted by: H. KLeNOW, E. Lund and S.O. ANDERSEN 